\title{
Aplikasi Lubang Resapan Biopori Berkompos terhadap Peningkatan Fosfor pada Agroekosistem Kebun Kopi Robusta
}

\section{Application of Biopore Infiltration Hole with Compost to Increase Phosphorus in Robusta Coffee Plantations}

\author{
Soemarno $^{1 *}$, Yusuf Mahardika Nurin ${ }^{2}$, Dinda Mahartian Yunita ${ }^{3}$, Atiqah Aulia Hanuf ${ }^{*}$ \\ ${ }^{1}$ Department of Soil Sciences, Faculty of Agriculture, Universitas Brawijaya, Malang, Jawa Timur, 65145, Indonesia \\ 2,3 Undergraduate Program in Soil Sciences, Faculty of Agriculture, Universitas Brawijaya, Malang, Jawa Timur, 65145, Indonesia \\ ${ }^{4}$ Magister Program in Soil and Water Management, Faculty of Agriculture, Universitas Brawijaya, Malang, Jawa Timur, 65145, Indonesia
}

Received 13 December 2020; Accepted 30 May 2021; Published 30 June 2021

\begin{abstract}
Sloping topography, clay textures and improper fertilizer application create a high risk of surface runoff and nutrient loss. Phosphorus occurs as an important nutrient in coffee beans. The objective of this research is to analyze the effects of biopore infiltration hole with compost $(\mathrm{BIHC})$ on the total and available phosphorus in robusta coffee in Bangelan plantation, Malang. A complete randomized block design with 4 replications was applied and the treatments consisted of control and BIHC. The BIHC process involved biopore hole depth of 30 and $60 \mathrm{~cm}$ for the goat manure and coffee pulp compost, respectively. Several parameters were also observed, including $\mathrm{pH}$, total and available phosphorus as well as soil organic carbon (SOC) between 0-20, 20-40 and 40-60 cm in soil depth. Subsequently, the analysis of variance (ANOVA) and Duncan's Multiple Range Test (DMRT) were used to comprehend the data. The results showed the ability of BIHC to significantly increase the $\mathrm{pH}, \mathrm{SOC}$ and total- $\mathrm{P}$, compared to the control with less available-P. These total-P improvements up to $103.27,108.73$ and $132.09 \%$ were reported at soil depths between $0-20,20-40$ and $40-60 \mathrm{~cm}$, respectively, while available-P were possibly enhanced up to $77.59,28.27$ and $151.99 \%$ at corresponding depth ranges.
\end{abstract}

Keywords: Biopore Depth; Coffea canephora; Coffee Pulp Compost; Goat Manure Compost

Cite this as (CSE Style): Soemarno, Nurin YM, Yunita DM, Hanuf AA. 2021. Aplikasi Lubang Resapan Biopori Berkompos (LRBB) terhadap peningkatan fosfor pada agroekosistem kebun kopi robusta. Agrotechnology Res $\mathrm{J}$. 5(1): 49-55. https://dx.doi.org/10.20961/agrotechresj.v5i1.46623.

\section{PENDAHULUAN}

Produksi kopi (Coffea canephora L.) memiliki beberapa permasalahan yang berakibat pada fluktuasi produksi kopi. Tahun 2018 produksi kopi mengalami peningkatan hingga 5,58\%, namun pada 2019 produksi kopi menurun 1,90\% (BPS, 2019). Produksi kopi Indonesia pada 2019, Sumatera Selatan, Lampung, Aceh, Sumatera Utara dan Jawa Timur merupakan lima provinsi yang memiliki areal perkebunan kopi terluas di Indonesia (BPS, 2019). Namun, Sumatera Utara (1.080 $\mathrm{kg} / \mathrm{ha}$ ), Jambi (968 kg.ha-1), Riau (951 kg.ha-1) dan Sumatera Selatan $\left(924 \mathrm{~kg} \cdot \mathrm{ha}^{-1}\right)$ dan Jawa Barat (808 $\mathrm{kg} . \mathrm{ha}^{-1}$ ) menjadi provinsi yang memiliki produktivitas tertinggi. Hal tersebut disebabkan karena penurunan kualitas tanah.

Salah satu upaya untuk meningkatkan produksi kopi adalah praktik pengelolaan lahan dengan pengelolaan kesuburan tanah dan pemupukan. Pengelolaan

\footnotetext{
${ }^{*}$ Corresponding Author:

1E-Mail:smno@ub.ac.id

${ }^{4} E$-mail: atiqahaulia6@gmail.com
}

kesuburan tanah dengan pupuk anorganik secara terus menerus dapat menyebabkan permasalahan dan merupakan teknologi pemupukan yang kurang tepat. Hal tersebut dapat menyebabkan kehilangan hara pupuk diantaranya melalui runoff dan penguapan sehingga mendorong terjadinya degradasi kualitas lahan. Penggunaan pupuk anorganik dalam jangka waktu panjang dapat menyebabkan penurunan kualitas fisika tanah dan perubahan komposisi mikroorganisme tanah (Lin et al. 2019). Pemupukan anorganik dalam jangka panjang juga dapat meningkatkan kemasaman tanah, pemadatan tanah dan penurunan aktivitas mikroorganisme (Li et al. 2016; Arafat et al. 2017; Li et al. 2017).

Unsur hara $\mathrm{P}$ merupakan unsur hara yang penting dalam pembentukan buah dan biji kopi. Di PTPN XII Bangelan, memiliki tanah yang berkembang dari bahan volkan dengan karakteristik kimia tanah meliputi $(\mathrm{pH})$ masam, fiksasi $\mathrm{P}$ yang tinggi, dan kandungan $\mathrm{Al} / \mathrm{Fe}$ yang tinggi (Nanzyo et al. 1993). Fiksasi P yang tinggi dapat menyebabkan rendahnya efisiensi pupuk fosfat (Kooch et al. 2020). Hal ini didukung oleh kondisi pH tanah yang rendah dan tanah kaya $\mathrm{Al}$ dan $\mathrm{Fe}$, kondisi ini mengakibatkan sebagian besar hara $P$ mengalami 
transformasi menjadi bentuk-bentuk Al-P dan Fe-P yang sukar larut (Dobermann et al. 2002; Saleque et al. 2004). Di lokasi penelitian, karakteristik fisika tanah (bertekstur liat) dan kemiringan lahan juga mempengaruhi ketersediaan unsur hara dan efisiensi pupuk. Tanah liat yang cepat jenuh dan lahan yang miring menyebabkan pupuk mudah mengalami limpasan permukaan.

Lubang Resapan Biopori Berkompos (LRBB) merupakan teknologi lubang resapan yang dibuat di permukaan tanah hingga kedalaman tertentu, dapat menampung runoff air hujan dan menjadi tempat untuk dekomposisi bahan organik (Permatasari 2015). Beberapa penelitian menunjukkan bahwa LRBB dapat diaplikasikan untuk mengurangi volume runoff (Landl et al. 2018; Clunes et al. 2021), meminimalkan kehilangan hara dan meningkatkan daya simpan air (Landl et al. 2019), meningkatkan porositas tanah (Reck et al. 2018), meningkatkan kapasitas air tersedia (Umasugi et al. 2021) dan meningkatkan kapasitas infiltrasi (Widiya dan Krisnawati 2017; Santos et al. 2018). Kompos yang terdapat pada LRBB diharapkan mampu membantu ketersediaan hara dalam tanah di sekitarnya. Berdasarkan hasil penelitian menunjukkan bahwa aplikasi bahan organik dapat memperbaiki karakteristik tanah (Kusumandari 2014). Selain itu, aplikasi kompos dan pupuk kandang juga dapat menurunkan fiksasi $P$ (Wei et al. 2017; Estrada-bonilla et al. 2021), menurunkan kelarutan $\mathrm{Al}$ dan meningkatkan $\mathrm{pH}$, sehingga dapat meningkatkan ketersediaan $\mathrm{P}$ dalam tanah (Peña-Méndez et al. 2005). Kebaharuan penelitian ini yaitu menggunakan Lubang Resapan Biopori Berkompos dengan pupuk organik untuk meningkatkan kandungan $\mathrm{P}$ total dan $\mathrm{P}$ tersedia dalam perakaran kopi. Ketersediaan hara $\mathrm{P}$ dalam tanah di zona perakaran kopi sangat penting bagi pertumbuhan dan produksi tanaman kopi. Penelitian ini dilakukan untuk mengetahui pengaruh LRBB terhadap kandungan $\mathrm{P}$-Total dan $\mathrm{P}$ tersedia dalam tanah di zona perakaran tanaman kopi robusta.

\section{BAHAN DAN METODE}

Penelitian dilakukan bulan Oktober 2019 di PTPN XII Kebun Bangelan, di Desa Bangelan Kecamatan Wonasari Kabupaten Malang, Jawa Timur. PTPN XII Kebun Bangelan terletak pada koordinat $8^{\circ} 04^{\prime} 38^{\prime \prime}$ LS dan 112028'58" BT. Penelitian menggunakan Rancangan Acak Kelompok Lengkap (RAK) dengan 7 perlakuan dan 4 ulangan. Plot penelitian terdiri dari 15 tanaman kopi robusta produktif dan 10 LRBB.

Perlakuan aplikasi LRBB yaitu tanpa LRBB (P0), LRBB $30 \mathrm{~cm}$ dan kompos kotoran kambing (P1), LRBB $30 \mathrm{~cm}$ dan kompos kulit kopi (P2), LRBB $60 \mathrm{~cm}$ dan kompos kotoran kambing (P3), LRBB $60 \mathrm{~cm}$ dan kulit kopi (P4), LRBB $30 \mathrm{~cm}$ dan $60 \mathrm{~cm}$ dan kompos kotoran kambing (P5) dan LRBB $30 \mathrm{~cm}$ dan $60 \mathrm{~cm}$ dan kulit kopi (P6). Input kompos yang diberikan masing-masing sebesar 12,02 ton.ha-1 untuk kompos kotoran kambing, dan 24,26 ton.ha ${ }^{-1}$ untuk kompos kulit kopi. Ilustrasi penerapan LRBB disajikan pada Gambar 1.

Pengambilan sampel tanah dilakukan dengan pengambilan komposit tanah dengan jarak pengambilan diantara batang tanaman dengan LRBB. Pengambilan sampel tanah dilakukan pada 60 HSA dan 90 HSA (Hari Setelah Aplikasi serta dilakukan pada kedalaman 0-20, 20-40, dan 40-60 cm. Variabel yang diamati adalah $P$ Total (metode pengabuan kering), P-Tersedia (metode
Bray 1), $\mathrm{pH}$ ( $\mathrm{pH}$ meter) dan C-Organik tanah (metode Walkley dan Black). Data yang diperoleh dianalisis menggunakan SPSS Data hasil pengamatan dianalisis menggunakan analisis sidik ragam berdasarkan uji $F$, kemudian dilanjutkan dengan Duncan's Multiple Range Test pada taraf 5\% dan uji korelasi untuk mengetahui keeratan hubungan antar parameter pengamatan.

\section{HASIL DAN PEMBAHASAN \\ Kandungan hara tanah dan kompos}

Kandungan unsur hara pada tanah di lokasi penelitian berkisar antara rendah hingga sedang. Kandungan $\mathrm{N}$-total tanah sebesar 0,16\%, C-organik tanah sebesar 1,14\%, P-total sebesar 226 ppm dan pH 5,6 . Kandungan hara kompos kotoran kambing meliputi $\mathrm{N}$-total sebesar 1,98\%, P-total 1,48 ppm, C-organik sebesar $32,28 \%$ dan $\mathrm{pH}$ sebesar 7,24. Kandungan $\mathrm{N}$ total kompos kulit kopi sebesar 1,04\%, P-total sebesar 0,25 ppm, C-organik sebesar 19,02 dan $\mathrm{pH} 7,18$. Berdasarkan kandungan tersebut, kompos telah memenuhi syarat kematangan kompos menurut Permentan 261/KPTS/SR. 310/M/4/2019.

\section{Pengaruh LRBB terhadap sifat kimia tanah}

Analisis ragam menunjukkan perlakuan LRBB berpengaruh nyata terhadap $\mathrm{pH}$ tanah pada kedalaman $0-20 \mathrm{~cm}$ (Tabel 1), namun tidak berbeda nyata pada kedalaman $20-40 \mathrm{~cm}$ dan $40-60 \mathrm{~cm}$. Perlakuan LRBB 30 $\mathrm{cm}$ dengan kompos kotoran kambing (P1) dan LRBB $30+60 \mathrm{~cm}$ dengan kompos kotoran kambing (P5) berbeda nyata dibandingkan dengan perlakuan LRBB 60 $\mathrm{cm}$ dengan kompos kotoran kambing (P3) dan LRBB $30+60 \mathrm{~cm}$ dengan kompos kulit kopi (P6). Berdasarkan rata-rata nilai $\mathrm{pH}$ tanah pada semua kedalaman, LRBB cenderung meningkatkan $\mathrm{pH}$ tanah, meskipun secara statistik tidak signifikan. Aplikasi pupuk organik pada Entisol mampu meningkatkan $\mathrm{pH}$ secara signifikan pada perlakuan aplikasi kotoran ayam 15 ton.ha-1 dibandingkan dengan kontrol (Afandi et al. 2015). Peningkatan $\mathrm{pH}$ tanah disebabkan oleh proses dekomposisi bahan organik yang melepaskan senyawasenyawa organik baik asam organik maupun kation basa (Ano dan Ubochi 2007; Fekadu et al. 2018). Asam-asam organik yang dilepaskan dapat mengikat ion $\mathrm{H}^{+}$sehingga pH meningkat (Hamed et al. 2014). Ikatan ini terjadi karena asam organik memiliki gugus karboksil yang memiliki muatan negatif sehingga dapat mengikat ion $\mathrm{H}^{+}$ (Qin et al. 2021). Asam organik juga mengikat $\mathrm{Al}^{3+}$ dan $\mathrm{Fe}^{2+}$ yang membentuk senyawa khelat sehingga tidak dapat terhidrolisis kembali. Kation basa yang dihasilkan pada proses dekomposisi bahan organik menghasilkan ion $\mathrm{OH}^{-}$yang dapat menetralisir ion $\mathrm{H}^{+}$.

C-organik tanah meningkat pada semua kedalaman tanah. Hasil penelitian menunjukkan bahwa LRBB berbeda nyata ( $p \leq 0.05$ ) terhadap C-organik tanah dibandingkan perlakuan kontrol. Penambahan bahan organik tanah berupa kompos kulit kopi dan kompos kotoran kambing mampu meningkatkan C-organik tanah. Perlakuan LRBB kombinasi $30 \mathrm{~cm}$ dan $60 \mathrm{~cm}$ mampu meningkatkan kandungan C-organik tanah pada semua kedalaman. Persentase peningkatan pada kedalaman 0-60 cm sebesar 1,8\% hingga 7,64\% dibandingkan kontrol.

Hasil analisis ragam menunjukkan perlakuan LRBB berpengaruh nyata terhadap kandungan P-total tanah dibandingkan kontrol (Tabel 2). Berdasarkan Tabel 2, 
semua perlakuan LRBB meningkatkan kandungan $P$ total tanah. Kedalaman $0-20 \mathrm{~cm}$ dan $40-60 \mathrm{~cm}$ menunjukkan bahwa perlakuan LRBB 30+60cm dengan kompos kulit kopi (P6) berbeda nyata dengan semua perlakuan. Pada kedalaman $20-40 \mathrm{~cm}$, nilai P-total tanah tertinggi ditunjukkan pada perlakuan LRBB $30 \mathrm{~cm}$ dengan kompos kulit kopi (P3) dan berbeda nyata dengan semua perlakuan. Beberapa penelitian melaporkan bahwa aplikasi kompos dan pupuk kandang meningkatkan kandungan P-total tanah (Huang et al. 2011; Pagliari 2014; Chen et al. 2020). Dekomposisi bahan organik menghasilkan asam-asam organik yang berpengaruh terhadap peningkatan P-total tanah. Perlakuan dengan tambahan bahan organik meningkatkan kandungan $\mathrm{P}$ tanah dan $\mathrm{P}$ tersedia tanah (Hastuti dan Rohmiyati 2020).

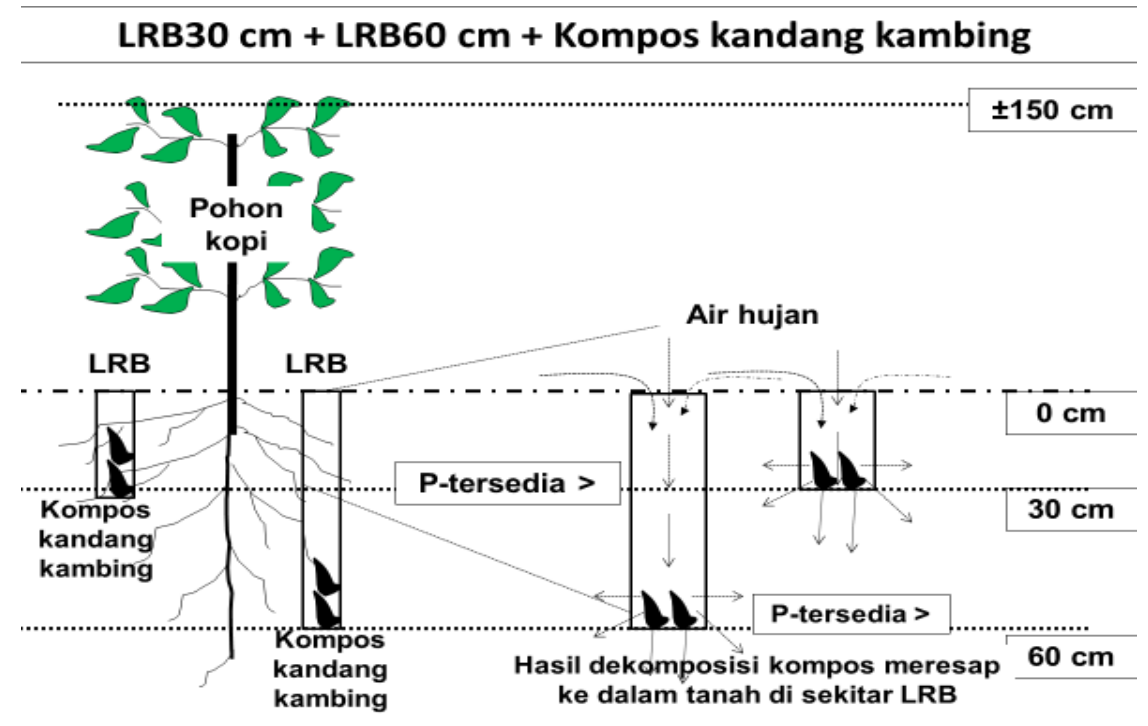

Gambar 1. Ilustrasi keterkaitan antara aplikasi kompos dengan P-tersedia pada perlakuan LRB30cm+LRB60cm+kompos kotoran kambing

Tabel 1. Pengaruh LRBB terhadap $\mathrm{pH}$ tanah

\begin{tabular}{llccc}
\hline \multirow{2}{*}{ Perlakuan } & \multicolumn{3}{c}{$\mathrm{pH}$ Tanah pada kedalaman tanah $(\mathrm{cm})$} & \\
\cline { 2 - 4 } & $0-20$ & $20-40$ & $40-60$ & Rata-rata \\
\cline { 2 - 3 } Sebelum Perlakuan & 5,44 & 5,04 & 5,00 & \\
\hline tanpa LRBB & $5,29 \mathrm{ab}$ & 5,27 & 5,15 & 5,24 \\
LRBB $30 \mathrm{~cm}$ dan kompos kotoran kambing & $5,15 \mathrm{a}$ & 5,38 & 5,40 & 5,31 \\
LRBB $30 \mathrm{~cm}$ dan kompos kulit kopi & $5,29 \mathrm{ab}$ & 5,20 & 5,36 & 5,28 \\
LRBB $60 \mathrm{~cm}$ dan kompos kotoran kambing & $5,59 \mathrm{~b}$ & 5,33 & 5,41 & 5,44 \\
LRBB $60 \mathrm{~cm}$ dan kompos kulit kopi & $5,38 \mathrm{ab}$ & 5,49 & 5,31 & 5,39 \\
LRBB $30 \mathrm{~cm}$ dan $60 \mathrm{~cm}$ dan kompos kotoran kambing & $5,13 \mathrm{a}$ & 5,45 & 5,34 & 5,31 \\
LRBB $30 \mathrm{~cm}$ dan $60 \mathrm{~cm}$ dan kompos kulit kopi & $5,50 \mathrm{~b}$ & 5,20 & 5,32 & 5,34 \\
\hline
\end{tabular}

Keterangan: Angka-angka yang diikuti huruf sama pada kolom sama menunjukkan tidak nyata pada uji Jarak Berganda Duncan taraf $5 \%$

Tabel 2. Pengaruh LRBB terhadap P-Total tanah

\begin{tabular}{|c|c|c|c|c|}
\hline \multirow[t]{2}{*}{ Perlakuan } & \multicolumn{3}{|c|}{$\begin{array}{c}\text { Kandungan P-total (ppm) pada } \\
\text { kedalaman tanah }(\mathrm{cm})\end{array}$} & \multirow{3}{*}{ Rata-Rata } \\
\hline & $0-20$ & $20-40$ & $40-60$ & \\
\hline Sebelum Perlakuan & 51,40 & 34,33 & 27,29 & \\
\hline tanpa LRBB & $97,56 a$ & $57,50 a$ & $53,95 \mathrm{a}$ & 69,67 \\
\hline LRBB $30 \mathrm{~cm}$ dan kompos kotoran kambing & $102,97 a b$ & $137,21 d$ & $91,92 b$ & 110,70 \\
\hline LRBB 30 cm dan kompos kulit kopi & $104,71 b$ & $214,65 e$ & $72,98 b$ & 130,78 \\
\hline LRBB $60 \mathrm{~cm}$ dan kompos kotoran kambing & $99,07 a b$ & $55,65 a$ & $103,59 \mathrm{c}$ & 86,10 \\
\hline LRBB 60 cm dan kompos kulit kopi & $179,24 d$ & $77,66 b$ & $104,53 \mathrm{c}$ & 120,48 \\
\hline LRBB $30 \mathrm{~cm}$ dan $60 \mathrm{~cm}$ dan kompos kotoran kambing & $117,62 c$ & $108,69 c$ & $117,88 \mathrm{~d}$ & 114,73 \\
\hline LRBB $30 \mathrm{~cm}$ dan $60 \mathrm{~cm}$ dan kompos kulit kopi & $198,31 \mathrm{e}$ & $120,02 c$ & $125,21 \mathrm{e}$ & 147,85 \\
\hline
\end{tabular}

Keterangan: Angka-angka yang diikuti huruf sama pada kolom sama menunjukkan tidak nyata pada uji Jarak Berganda Duncan taraf $5 \%$ 
Ilustrasi skema peningkatan P-tersedia yang disebabkan oleh aplikasi LRBB disajikan pada Gambar 1. Hasil analisis ragam menunjukkan tidak ada perbedaan nyata pada kandungan P-tersedia tanah pada semua perlakuan (Tabel 3). Namun, rata-rata kandungan P-tersedia tanah pada semua kedalaman (0$60 \mathrm{~cm}$ ) dan semua perlakuan cenderung meningkat dibandingkan dengan perlakuan kontrol. Hal ini didukung dengan korelasi nyata antara $\mathrm{P}$-tersedia terhadap $\mathrm{pH}$ tanah sebesar $r=0,416^{* *}(p \leq 0,01)$. Kandungan $P$ tersedia tertinggi ditunjukkan pada perlakuan P6. Hal ini mengindikasikan bahwa perlakuan LRBB dapat meningkatkan kandungan P-tersedia dalam tanah, meskipun peningkatan ini tidak signifikan pada $p=0,05$. Peningkatan P-tersedia ini juga mengindikasikan adanya proses mineralisasi P-organik yang ada dalam kompos. Rendahnya peningkatan kandungan P-tersedia ini disebabkan adanya reaksi antara $\mathrm{P}$-tersedia dengan komponen tanah masam menjadi bentuk $\mathrm{P}$ yang tidak larut. Pada keadaan tanah masam ( $\mathrm{pH}$ rendah) anion fosfat diikat oleh logam seperti $\mathrm{Al}$, dan $\mathrm{Fe}$ menjadi senyawa kompleks yang tidak larut (Agbenin 2003; Ifansyah 2014).

Bahan organik yang terdekomposisi menghasilkan asam-asam organik yang berperan sebagai pengkhelat (Gusnidar et al. 2010). Ditambahkan bahwa peningkatan $P$ terjadi karena adanya pembentukan senyawa kompleks Al sebagai hasil dari dekomposisi bahan organik sehingga kandungan Al-dd menurun dan mengurangi adsorpsi P oleh Al (Haynes dan Mokolobate 2001). Banyaknya $P$ total dalam tanah tidak berpengaruh terhadap ketersediaan P. Bentuk yang tersedia bagi tanaman hanya sebagian kecil dari jumlah yang ada di dalam tanah. Hal ini disebabkan karena $P$ mudah terikat dengan unsur $\mathrm{Al}$ dan $\mathrm{Fe}$ pada tanah masam (Wang et al. 2021).

Peningkatan P-tersedia dipengaruhi oleh peningkatan $\mathrm{pH}$. Dekomposisi bahan organik yang akan menghasilkan asam-asam organik yang berperan sebagai pengkhelat, sehingga dapat meningkatkan $\mathrm{pH}$ tanah yang menyebabkan ketersediaan $\mathrm{P}$ dalam tanah. Hal ini sesuai dengan Gusnidar et al. (2010) yang menyatakan bahwa dalam proses inkubasi, titonia akan mengalami proses dekomposisi sehingga akan menghasilkan asam-asam organik, hal tersebut diakibatkan karena bahan organik tersebut sebagian besar telah terurai dengan baik sehingga akan menghasilkan asam-asam organik (Gusnidar et al. 2010). Penelitian mengenai pengaruh aplikasi kompos kulit kopi, rock phosphate dan kombinasi keduanya menunjukkan bahwa bahan-bahan tersebut mampu meningkatkan kandungan $\mathrm{P}$ tersedia, dimana perlakuan kombinasi keduanya mendapatkan hasil tertinggi (Shitindi dan Mrema 2019).

\section{Hubungan karakteristik tanah terhadap kandungan P-total dan P-tersedia}

Hasil uji korelasi antara $\mathrm{pH}$ dan C-organik dengan kandungan P-total dan P-tersedia menunjukkan adanya keeratan hubungan yang signifikan (Tabel 4). $\mathrm{pH}$ dan kandungan P-tersedia pada kedalaman 0-20 cm menunjukkan korelasi positif signifikan $\left(r=0,416^{* *}\right)$ artinya kenaikan $\mathrm{pH}$ akan berpengaruh nyata terhadap kenaikan kandungan P-tersedia. Hasil uji korelasi pada kedalaman 20-40 cm, pH dan P-total menunjukkan korelasi positif signifikan $\left(r=0,24^{\star}\right)$. Hasil uji korelasi pada kedalaman 40-60 cm, pH dan P-total menunjukkan nilai positif signifikan $\left(r=0,39^{*}\right)$. Kandungan C-organik dengan P-total pada kedalaman 40-60 cm menunjukkan korelasi positif signifikan $\left(r=0,55^{\star *}\right)$. Bahan organik dapat meningkatkan $\mathrm{P}$ tersedia dalam ikatan $\mathrm{P}$ tanah (Agbenin dan Igbokwe 2006; Gichangi dan Mnkeni 2009). Kandungan $P$ tersedia dipengaruhi oleh bahan organik tanah, $\mathrm{pH}$ dan $\mathrm{Al}$, Fe dan $\mathrm{Ca}$ yang dapat ditukar dan larut (Opala et al. 2010). Hal ini menunjukkan bahwa aplikasi kompos meningkatkan kandungan C-organik dan kandungan P-total dalam tanah. Hal ini dapat terjadi karena kompos yang berasal dari kompos kulit kopi dan kompos kotoran kambing mengandung sejumlah Corganik dan P-total. Hal yang serupa telah dilaporkan pula oleh beberapa peneliti (Boateng dan Ayisi 2015; Herencia dan Maqueda 2016; Hariyono 2018).

Beberapa parameter belum menunjukkan peningkatan signifikan pada P-total dan P-tersedia, serta belum terlihat pengaruhnya pada semua kedalaman. Hal ini disebabkan karena kurangnya waktu pengamatan sehingga hasil dekomposisi dari LRBB ke tanah belum meresap secara lebih optimal. Hasil analisis tersebut sesuai dengan Kannan et al. (2021) bahwa ketersediaan $P$ di dalam tanah tergantung kepada: (1) jumlah dan jenis mineral tanah, (2) $\mathrm{pH}$ tanah, (3) pengaruh kation, (4) pengaruh anion, (5) tingkat kejenuhan $P$, (6) bahan organik, (7) waktu dan suhu, dan (8) penggenangan.

Tabel 3. Pengaruh LRBB terhadap P-tersedia tanah

\begin{tabular}{lcccc}
\hline \multirow{2}{*}{ Perlakuan } & \multicolumn{3}{c}{ Kandungan P-Tersedia (ppm) pada } \\
& \multicolumn{3}{c}{ kedalaman tanah (cm) } & \multirow{2}{*}{ Rata-rata } \\
\cline { 2 - 4 } & $0-20$ & $20-40$ & $40-60$ & \\
\hline Sebelum Perlakuan & 5,44 & 5,04 & 5,00 & \\
\hline tanpa LRBB & 0,406 & 0,626 & 0,402 & 0,477 \\
LRBB 30 cm dan kompos kotoran kambing & 0,438 & 0,539 & 0,622 & 0,533 \\
LRBB $30 \mathrm{~cm}$ dan kompos kulit kopi & 0,413 & 0,634 & 0,626 & 0,557 \\
LRBB $60 \mathrm{~cm}$ dan kompos kotoran kambing & 0,490 & 0,718 & 0,418 & 0,542 \\
LRBB $60 \mathrm{~cm}$ dan kompos kulit kopi & 1,385 & 0,422 & 0,434 & 0,747 \\
LRBB 30 cm dan 60 cm dan kompos kotoran kambing & 0,401 & 0,620 & 0,599 & 0,539 \\
LRBB 30 cm dan 60 cm dan kompos kulit kopi & 0,721 & 0,803 & 1,013 & 0,846 \\
\hline
\end{tabular}

Keterangan: Angka-angka yang diikuti huruf sama pada kolom sama menunjukkan tidak nyata pada uji Jarak Berganda Duncan taraf $5 \%$ 
Tabel 4. Karakteristik tanah terhadap P-total dan P-tersedia

\begin{tabular}{|c|c|c|c|c|}
\hline Peubah & $\mathrm{pH}$ & P-Tersedia & P-Total & C-Organik \\
\hline \multicolumn{5}{|c|}{$0-20 \mathrm{~cm}$} \\
\hline $\mathrm{pH}$ & 1 & & & \\
\hline P-Tersedia & $0,416^{* *}$ & 1 & & \\
\hline P-Total & 0,169 & 0,188 & 1 & \\
\hline C-Organik & $-0,045$ & 0,204 & 0,158 & 1 \\
\hline \multicolumn{5}{|c|}{$20-40 \mathrm{~cm}$} \\
\hline $\mathrm{pH}$ & 1 & & & \\
\hline P-Tersedia & 0,189 & 1 & & \\
\hline P-Total & $0,239^{\star}$ & 0,057 & 1 & \\
\hline C-Organik & 0,154 & 0,044 & 0,041 & 1 \\
\hline \multicolumn{5}{|c|}{$40-60 \mathrm{~cm}$} \\
\hline pH & 1 & & & \\
\hline P-Tersedia & 0,19 & 1 & & \\
\hline P-Total & $0,39^{\star *}$ & 0,19 & 1 & \\
\hline C-Organik & $0,30^{\star \star}$ & 0,04 & $0,55^{\star \star}$ & 1 \\
\hline
\end{tabular}

Keterangan: * tingkat signifikansi kuat pada uji taraf $5 \%(r=0,2146) ;{ }^{* *}$ tingkat signifikansi kuat pada taraf uji $1 \%(r=0,2535)$

LRBB merupakan lubang tempat dekomposisi bahan organik yang telah diaplikasikan dengan kedalaman tertentu. Penambahan bahan organik pada LRBB diharapkan dapat meningkatkan populasi organisme tanah sehingga dapat meningkatkan kualitas tanah. Selain itu, LRBB berperan dalam efisiensi pemupukan dan optimalisasi penyerapan hara oleh akar tanaman. Kondisi lokasi penelitian yang memiliki risiko limpasan permukaan yang tinggi menyebabkan LRBB menjadi solusi dalam menurunkan laju limpasan permukaan. Laju limpasan permukaan dapat ditekan dengan cara peningkatan kualitas tanah seperti menurunkan kemungkinan bahan organik yang hilang dari tanah. Maka, kompos yang diaplikasikan dapat terurai dengan optimal dan hasil dekomposisi dari LRBB dapat disalurkan ke dalam tanah dan diserap oleh akar tanaman.

\section{KESIMPULAN}

LRBB meningkatkan kandungan P-total tanah secara nyata pada keseluruhan kedalaman tanah. Nilai tertinggi ditunjukkan pada perlakuan LRBB $30+60 \mathrm{~cm}$ dengan kompos kulit kopi dengan peningkatan sebesar 112,21\% dibandingkan kontrol. Perlakuan LRBB dapat meningkatkan kandungan $\mathrm{P}$-tersedia yang lebih tinggi dibandingkan dengan kontrol. Nilai tertinggi ditunjukkan pada perlakuan LRBB $30+60 \mathrm{~cm}$ dengan kompos kulit kopi dengan peningkatan sebesar $77,36 \%$ dibandingkan kontrol.

\section{UCAPAN TERIMA KASIH}

Ucapan terimakasih kepada PTPN XII Bangelan yang telah memberikan izin. Penelitian ini terlaksana atas dukungan dari Program Hibah Profesor tahun anggaran 2020 dengan kontrak No. 2338/UN10.F04/PN/2020.

\section{DAFTAR PUSTAKA}

Afandi FN, Siswanto B, Nuraini Y. 2015. Pengaruh pemberian berbagai jenis bahan organik terhadap tifat kimia tanah pada pertumbuhan dan produksi tanaman ubi jalar di entisol Ngrangkah Pawon, Kediri. J Tanah Sumberdaya Lahan. 2(2):237-244.
Agbenin JO. 2003. Extractable iron and aluminum effects on phosphate sorption in a savanna alfisol. Soil Sci Soc Am J. 67(2):589-595. https://dx.doi.org/10.2136/sssaj2003.5890.

Agbenin JO, Igbokwe SO. 2006. Effect of soil-dung manure incubation on the solubility and retention of applied phosphate by a weathered tropical semi-arid soil. Geoderma. 133(3-4):191-203. https://dx.doi.org/10.1016/j.geoderma.2005.07.006.

Ano AO, Ubochi Cl. 2007. Neutralization of soil acidity by animal manures: mechanism of reaction. Afr $\mathrm{J}$ Biotechnol. 6(4):364-368.

Arafat $Y$, Wei X, Jiang $Y$, Chen T, Saqib HSA, Lin S, Lin W. 2017. Spatial distribution patterns of rootassociated bacterial communities mediated by root exudates in different aged ratooning tea monoculture systems. Int J Mol Sci. 18(8):1-16. https://dx.doi.org/10.3390/ijms18081727.

[BPS] Badan Pusat Statistik. 2019. Indonesian coffee statistics. In: Sub Direktorat Statistik Tanaman Perkebunan, editor. Jakarta (ID): BPS-Statistics Indonesia. $85 \mathrm{p}$.

Boateng KGA, Ayisi CL. 2015. The effect of organic manures on soil fertility and microbial biomass carbon, nitrogen and phosphorus under maizecowpea intercropping system. Discourse J Agric Food Sci. 3(4):65-77.

Chen X, Wang L, Niu Z, Zhang M, Li C, Li J. 2020. The effects of projected climate change and extreme climate on maize and rice in the Yangtze River Basin, China. Agric For Meteorol. 282-283(December 2019):107867. https://dx.doi.org/10.1016/j.agrformet.2019.107867.

Clunes J, Dörner J, Pinochet D. 2021. How does the functionality of the pore system affects inorganic nitrogen storage in volcanic ash soils ? Soil Tillage Res.

205:104802. https://dx.doi.org/10.1016/j.still.2020.104802.

Dobermann A, George T, Thevs N. 2002. Phosphorus fertilizer effects on soil phosphorus pools in acid upland soils. Soil Sci Soc Am J. 66(2):652-660. https://dx.doi.org/10.2136/sssaj2002.6520. 
Estrada-bonilla GA, Durrer A, Cardoso EJBN. 2021. Use of compost and phosphate-solubilizing bacteria affect sugarcane mineral nutrition, phosphorus availability, and the soil bacterial community. Appl Soil Ecol. 157:103760. https://doi.org/10.1016/j.apsoil.2020.103760.

Fekadu E, Kibret K, Bedadi B, Melese A, Yitaferu B. 2018. Organic and inorganic amendments on soil chemical properties at different period of incubation of acidic soil. Eurasian J Soil Sci. 7(3):273-283. https://dx.doi.org/10.18393/ejss.435095.

Gichangi EM, Mnkeni PNS. 2009. Effects of goat manure and lime addition on phosphate sorption by two soils from the transkei region, South Africa. Commun Soil Sci Plant Anal. 40(21-22):3335-3347. https://dx.doi.org/10.1080/00103620903325943.

Gusnidar G, Hakim N, Prasetyo TB. 2010. Inkubasi titonia pada tanah sawah terhadap asam-asam $\begin{array}{llll}\text { organik. } & \mathrm{J} & \text { Solum. } & 7(1): 7 .\end{array}$ https://dx.doi.org/10.25077/js.7.1.7-18.2010.

Hamed MH, M.A. Desoky. AM, Ghallab. MA, M.A. F. 2014. Effect of incubation periods and some organic materials on phosphorus forms in calcareous soils. Int J Technol Enhanc Emerg Eng Res. 2(6):2347-4289.

Hariyono D. 2018. The effect planting hole size and manure on vegetative growth of golden teak (Tectona grandis L.). J Degrad Min L Manag. 5(3):1293-1297. https://dx.doi.org/10.15243/jdmlm.2018.053.1293.

Hastuti PB, Rohmiyati SM. 2020. Application of empty fruit bunches compost and types of $p$ fertilizer on the growth and phosphorus uptake in oil palm seedlings. Agrotechnology Res J. 4(2):59-64. https://dx.doi.org/10.20961/agrotechresj.v4i2.40784.

Haynes RJ, Mokolobate MS. 2001. Amelioration of Al toxicity and $P$ deficiency in acid soils by additions of organic residues: A critical review of the phenomenon and the mechanisms involved. Nutr Cycl Agroecosystems. 59(1):47-63. https://dx.doi.org/10.1023/A:1009823600950.

Herencia JF, Maqueda C. 2016. Effects of time and dose of organic fertilizers on soil fertility, nutrient content and yield of vegetables. J Agric Sci. 154(8):1343-1361. https://dx.doi.org/10.1017/S0021859615001136.

Huang S, Ma Y, Bao D, Guo D, Zhang S. 2011. Manures behave similar to superphosphate in phosphorus accumulation in long-term field soils. Int J Plant Prod. 5(2):135-146. https://dx.doi.org/10.22069/ijpp.2012.727.

Ifansyah H. 2014. Soil pH and solubility of aluminum, iron, and phosphorus in ultisols: the roles of humic acid. J Trop Soils. 18(3):203-208.

Kannan $\mathrm{P}$, Paramasivan M, Marimuthu S, Swaminathan C, Bose J. 2021. Applying both biochar and phosphobacteria enhances Vigna mungo L. growth and yield in acid soils by increasing soil pH, moisture content, microbial growth and $\mathrm{P}$ availability. Agric Ecosyst $\quad$ Environ. 308:107258. https://doi.org/10.1016/j.agee.2020.107258.

Kooch Y, Ehsani S, Akbarinia M. 2020. Stratification of soil organic matter and biota dynamics in natural and anthropogenic ecosystems. Soil Tillage Res. 200:104621. https://doi.org/10.1016/j.still.2020.104621.
Kusumandari A. 2014. Soil erodibility of several types of green open space areas in Yogyakarta city, Indonesia. Procedia Environ Sci. 20:732-736. https://dx.doi.org/10.1016/j.proenv.2014.03.087.

Landl M, Schnepf A, Vanderborght J, Uteau D, Athmann M, Kautz T, Perkons U, Vereecken H. 2018. The impact of biopores on root growth and root water uptake under different soil physical conditions - a simulation study. Geophys Res Abstr. 20:4359. https://dx.doi.org/10.2136/vzj2018.11.0196.

Li Y, Li Z, Arafat Y, Lin Weiwei, Jiang Y, Weng B, Lin Wenxiong. 2017. Characterizing rhizosphere microbial communities in long-term monoculture tea orchards by fatty acid profiles and substrate utilization. Eur J Soil Biol. 81:48-54. https://dx.doi.org/10.1016/j.ejsobi.2017.06.008.

Li YC, Li Z, Li ZW, Jiang YH, Weng BQ, Lin WX. 2016. Variations of rhizosphere bacterial communities in tea (Camellia sinensis L.) continuous cropping soil by high-throughput pyrosequencing approach. J Appl Microbiol. https://dx.doi.org/10.1111/jam.13225.

Lin Weiwei, Lin M, Zhou H, Wu H, Li Z, Lin Wenxiong. 2019. The effects of chemical and organic fertilizer usage on rhizosphere soil in tea orchards. PLoS One. 14(5):1-16. https://dx.doi.org/10.1371/journal.pone.0217018.

Nanzyo M, Shoji S, Dahlgren R. 1993. Chapter 7 physical characteristics of volcanic ash soils. In: Shoji S, Nanzyo M, Dahlgren R, editors. Developments in soil science. Amsterdam (NL): Elsevier. 21:189-207. https://dx.doi.org/10.1016/S0166-2481(08)70268-X.

Opala PA, Okalebo JR, Othieno CO, Kisinyo P. 2010. Effect of organic and inorganic phosphorus sources on maize yields in an acid soil in western Kenya. Nutr Cycl Agroecosystems. 86(3):317-329. https://dx.doi.org/10.1007/s10705-009-9294-3.

Pagliari PH. 2014. Chapter 8: Variety and solubility of phosphorus forms in animal manure and their effects on soil test phosphorus. In: He Z, Zhang H, editors. Applied manure and nutrient chemistry for sustainable agriculture and environment. p. 142-161. https://doi.org/10.1007/978-94-017-8807-6_8.

Peña-Méndez EM, Havel J, Patočka J. 2005. Humic substance - Compounds of still unknown structure: Applications in agriculture, industry, environment, and biomedicine. J Appl Biomed. 3(1):13-24. https://dx.doi.org/10.32725/jab.2005.002.

Permatasari L. 2015. Biopore infiltration hole: "one day for biopore" as an alternative prevent flood. Int J Adv Sci Eng Technol. 3(2):6-9.

Qin R, Su C, Mo T, Liao L, Zhu F, Chen Y, Chen M. 2021. Effect of excess sludge and food waste feeding ratio on the nutrient fractions, and bacterial and fungal community during aerobic. Bioresour Technol. 320(Part A):124339. https://doi.org/10.1016/j.biortech.2020.124339.

Reck A, Jackisch C, Hohenbrink TL, Schröder B, Zangerlé A, Schaik L. 2018. Impact of temporal macropore dynamics on infiltration: field experiments and model simulations. Vadose Zo J. 17(1):170147. https://dx.doi.org/10.2136/vzj2017.08.0147. 
Saleque MA, Naher UA, Islam A, Pathan ABMBU, Hossain ATMS, Meisner CA. 2004. Inorganic and Organic Phosphorus Fertilizer Effects on the Phosphorus Fractionation in Wetland Rice Soils. Soil Sci Soc Am J. 68(5):1635-1644. https://dx.doi.org/10.2136/sssaj2004.1635.

Santos M, Rocha F, Silva D, Ferraz AC, Andrade JT, Marjorie K, Herrera S, Lima WG. 2018. Triazole chalcones : lack of antibacterial , anti - candida , and anti - dengue virus activities. J Pharm Negat Results. 9(1):39-43.

Shitindi M., Mrema JP. 2019. Composting coffee pulp with Minjingu phosphate rock improves phosphorus availability for tomato uptake. Afr J Agric Res. 14(25):1051-1057. https://dx.doi.org/10.5897/ajar2018.13089.

Umasugi B, Prijono S, Soemarno, Ariffin. 2021. Improvement of soil moisture storage in clove plantation land using biopore technology and organic material litters. J Degrad Min L Manag. 8(2):2601-2610. https://dx.doi.org/10.15243/jdmlm.2021.082.2601.
Wang Q, Shaheen SM, Jiang Y, Li R, Slaný M. 2021. $\mathrm{Fe} / \mathrm{Mn}$ - and P-modified drinking water treatment residuals reduced $\mathrm{Cu}$ and $\mathrm{Pb}$ phytoavailability and uptake in a mining soil. J Hazard Mater. 403. https://dx.doi.org/10.1016/j.jhazmat.2020.123628.

Wei Y, Zhao Yue, Fan Y, Lu Q, Li M, Wei Q, Zhao Yi, Cao Z, Wei Z. 2017. Impact of phosphate-solubilizing bacteria inoculation methods on phosphorus transformation and long-term utilization in composting. Bioresour Technol. 241:134-141. http://dx.doi.org/10.1016/j.biortech.2017.05.099.

Widiya M, Krisnawati Y. 2017. Perbandingan efektifitas laju resapan air berdasarkan variasi dan umur sampah. In: Herlinda S, Nirmala K, Novra A, Sahari B, Suwandi, Tanbiyaskur, Puspitahati, Syafutri MI, Sasanti AD, editors. Pengembangan ilmu dan teknologi pertanian bersama petani lokal untuk optimalisasi lahan suboptimal. Prosiding Seminar Nasional Lahan Suboptimal Tahun 2017; 19-20 Oktober 2017; Palembang, ID. Palembang(ID): Unsri Press. p. 489-496. 